\title{
Hubungan Pemakaian Alat Ortodontik Cekat dengan Status Kebersihan Gigi dan Mulut Siswa SMA Kristen 1 Tomohon
}

\author{
Wulan K. D. Rambitan \\ Pritartha S. Anindita \\ Christy N. Mintjelungan
}

\author{
Program Studi Pendidikan Dokter Gigi Fakultas Kedokteran \\ Universitas Sam Ratulangi Manado \\ Email: wkdrambitan@gmail.com
}

\begin{abstract}
Fixed orthodontic devices are the most commonly used orthodontic appliances in the community especially adolescent because they have become an important part of lifestyle. Albeit, users of fixed orthodontic appliances do not realize that fixed orthodontic appliances could become a risk factor for poor dental and oral hygiene. This study was aimed to determine the relationship between the use of fixed orthodontic devices and the dental and oral hygiene status of students at SMA Kristen 1 Tomohon (senior high school). This was an analytical observational study with a cross sectional design. Subjects were 43 students who used fixed orthodontics appliances obtained by using total sampling method. The results showed that most subjects used fixed orthodontic appliance for less than one year $(58.1 \%)$. Moreover, the dental and oral hygiene status of most subjects were in the moderate category. The Chi-square showed a p-value of 0,060 for the relationship between the use of fixed orthodontic devices and the dental and oral hygiene status. Conclusion: There was no significant relationship between the duration of use of fixed orthodontic devices and the dental and oral hygiene status of students at SMA Kristen 1 Tomohon
\end{abstract}

Keywords: fixed orthodontic appliances, oral hygiene, adolescents

\begin{abstract}
Abstrak: Alat ortodontik cekat merupakan peralatan ortodontik yang paling sering dipakai oleh masyarakat khususnya remaja karena sudah menjadi bagian dari gaya hidup. Namun pemakai alat ortodontik cekat tidak menyadari bahwa alat ortodontik cekat merupakan faktor risiko terganggunya kebersihan gigi dan mulut. Penelitian ini bertujuan untuk mengetahui hubungan pemakaian alat ortodontik cekat dengan status kebersihan gigi dan mulut siswa SMA Kristen 1 Tomohon. Jenis penelitian ialah observasional analitik dengan desain potong lintang. Subyek penelitian yaitu 43 siswa yang memakai alat ortodontik cekat yang diperoleh dengan metode total sampling. Hasil penelitian menunjukkan pemakaian alat ortodontik cekat terbanyak yaitu di bawah satu tahun $(58,1 \%)$ dan status kebersihan gigi dan mulut berada dalam kategori sedang. Hasil uji Chi-square terhadap hubungan antara pemakaian alat ortodontik cekat dengan status kebersihan gigi dan mulut subyek penelitian mendapatkan nilai $\mathrm{p}=0,060$. Simpulan: Tidak terdapat hubungan bermakna antara lama pemakaian alat ortodontik cekat dengan status kebersihan gigi dan mulut siswa SMA Kristen 1 Tomohon.
\end{abstract}

Kata kunci: alat ortodontik cekat, kebersihan gigi dan mulut, remaja

Kesehatan gigi dan mulut merupakan salah satu faktor yang penting dalam kehidupan manusia. Saat ini kesehatan gigi dan mulut perlu mendapat perhatian lebih khususnya di Indonesia. ${ }^{1-4}$ Menurut Rahardjo, ${ }^{4}$ di negara berkembang khususnya Indonesia fasilitas dan dokter gigi serta akses ke fasilitas kesehatan masih terbatas, bahkan di kota-kota besar dinilai belum optimal.

Data RISKESDAS tahun 2013 menye- 
butkan bahwa masalah kesehatan gigi dan mulut di Indonesia sebesar 25,9\% sedangkan tahun 2007 sebesar 23,4\%. Hasil tersebut dapat menjelaskan bahwa terdapat peningkatan masalah kesehatan gigi dan mulut dari tahun ke tahun di Indonesia. Masalah kesehatan gigi dan mulut yang sering dialami yaitu karies, penyakit periodontal, dan maloklusi. ${ }^{5,6}$

Maloklusi yaitu penyimpangan gigi yang dianggap tidak memuaskan secara estetika dan fungsional yang jauh dari kata ideal. $^{7}$ Maloklusi dirawat dengan memakai alat ortodontik. $^{8}$ Alat ortodontik yang paling sering dipakai ialah alat ortodontik cekat. Terlepas dari tujuan perawatan ortodontik yang awalnya untuk meningkatkan kesehatan dan fungsi oral, ternyata terdaapt juga dampak negatif perawatan ortodontik. ${ }^{9,10}$

Salah satu kelompok masyarakat yang tertarik untuk memakai alat ortodontik ialah remaja. Menurut World Health Organization (WHO), remaja ialah orang muda yang usianya 10-19 tahun. ${ }^{11}$ Pada masa remaja telah terjadi perkembangan psikologis yang mengakibatkan timbulnya kesadaran dan keinginan untuk tampil terbaik. $^{8,10}$

Pemakaian alat ortodontik cekat dapat menyebabkan impaksi makanan yang berakibat lanjut terjadinya retensi plak. ${ }^{12,13}$ Penelitian yang dilakukan oleh Al-Anezi dan Harradine ${ }^{14}$ di Amerika menunjukkan bahwa pemakai alat ortodontik cekat merupakan salah satu faktor risiko terbentuknya plak. ${ }^{14,15}$ Hasil penelitian yang dilakukan oleh Attasi $^{16}$ di Arab Saudi menunjukkan bahwa $60 \%$ pasien pemakai alat ortodontik cekat memiliki tingkat kebersihan gigi dan mulut yang buruk yang disebabkan oleh masih kurangnya menjaga kebersihan gigi dan mulut khususnya pada pemakai alat ortodontik cekat.

Lama waktu pemakaian alat ortodontik cekat juga dapat memengaruhi kebersihan gigi dan mulut. Pemakaian alat ortodontik cekat biasanya dipakai selama 2 tahun. ${ }^{17}$ Alat ortodontik cekat menyebabkan perubahan flora normal rongga mulut. Penelitian yang dilakukan oleh Topaloglu et $\mathrm{al}^{18}$ di Turki menunjukkan terjadi peningkatan bakteri secara bermakna pada 3-6 bulan setelah pemakaian alat ortodontik cekat.

Penelitian ini bertujuan untuk mengetahui hubungan pemakaian alat ortodontik cekat dan status kebersihan gigi dan mulut siswa-siswi di SMA Kristen 1 Tomohon dengan menggunakan Oral Hygiene IndexSimplified (OHI-S).

\section{METODE PENELITIAN}

Jenis penelitian ini ialah observasional analitik dengan desain potong lintang. Penelitian dilakukan di SMA Kristen 1 Tomohon pada bulan Mei-Juni 2018.

Populasi penelitian yaitu seluruh siswa-siswi SMA Kristen 1 Tomohon yang memakai alat ortodontik cekat dan berusia 14-17 tahun. Pengambilan sampel menggunakan total sampling, dan yang memenuhi kriteria inklusi berjumlah 64 orang.

Dalam penelitian ini digunakan indeks Oral Hygiene Index Simplified (OHI-S) menurut Green dan Vermillion yang diperoleh dengan menjumlahkan nilai DI-S dan CI-S.

Data hasil penelitian diolah dan dianalisis menggunakan program statistical package for the social scienses (SPSS) Uji Chi-square digunakan untuk mengetahui hubungan antara pemakaian alat ortodontik cekat dengan status kebersihan gigi dan mulut.

\section{HASIL PENELITIAN}

Penelitian ini dilakukan di SMA Kristen 1 Tomohon yang terletak di Jln. Kampus Talete II Kelurahan Talete II Kecamatan Tomohon Tengah Kota Tomohon Provinsi Sulawesi Utara.

Jumlah subyek dalam penelitian ini sebanyak 43 siswa, yang terdiri atas 9 (20,9\%) laki-laki dan $34(79,1 \%)$ perempuan. Tabel 1 memperlihatkan distribusi frekuensi subyek berdasarkan usia dan didapatkan bahwa yang terbanyak ialah siswa berusia 15 tahun berjumlah 23 orang $(53,5 \%)$ sedangkan yang paling sedikit yaitu yang berusia 14 tahun sebanyak 4 orang $(9,3 \%)$. 
Tabel 1. Distribusi frekuensi subyek penelitian berdasarkan usia

\begin{tabular}{ccc}
\hline Usia (tahun) & $\mathbf{n}$ & $\mathbf{\%}$ \\
\hline 14 & 4 & 9.3 \\
15 & 23 & 53.5 \\
16 & 11 & 25.6 \\
17 & 5 & 11.6 \\
Total & 43 & 100 \\
\hline
\end{tabular}

Tabel 2 menampilkan distribusi frekuensi subyek berdasarkan lama pemakaian alat ortodontik cekat. Yang terbanyak ialah subyek yang memakai alat ortodontik cekat selama kurun waktu $<1$ tahun berjumlah 25 orang $(58,1 \%)$, sedangkan yang memakai alat ortodontik selama kurun waktu 1-2 tahun berjumlah 18 orang $(41,9 \%)$.

Tabel 2. Distribusi frekuensi subyek penelitian berdasarkan lama pemakaian alat ortodontik cekat

\begin{tabular}{ccc}
\hline $\begin{array}{l}\text { Lama pemakaian alat } \\
\text { rrtodontik cekat (tahun) }\end{array}$ & $\mathbf{n}$ & $\mathbf{( \% )}$ \\
\hline$<1$ & 25 & 58,1 \\
$1-2$ & 18 & 41,9 \\
$>2$ & 0 & 0 \\
\hline
\end{tabular}

Tabel 3 memperlihatkan distribusi subyek berdasarkan status kebersihan gigi dan mulut dan menunjukkan bahwa dari 43 subyek terdapat 13 orang $(30,2 \%)$ tergo- long kategori baik; 27 orang $(62,8 \%)$ tergolong kategori sedang; dan 3 orang $(7 \%)$ tergolong kategori buruk.

Tabel 3. Distribusi frekuensi subyek penelitian berdasarkan status kebersihan gigi dan mulut

\begin{tabular}{ccc}
\hline $\begin{array}{c}\text { Status kebersihan } \\
\text { gigi dan mulut }\end{array}$ & n & \% \\
\hline Baik & 13 & 30,2 \\
Sedang & 27 & 62,8 \\
Buruk & 3 & 7,0 \\
Total & 43 & 100 \\
\hline
\end{tabular}

Tabel 4 memperlihatkan hubungan pemakaian alat ortodontik cekat dengan status kebersihan gigi dan mulut Siswa SMA Kristen 1 Tomohon. Pemakai alat ortodontik cekat di bawah 1 tahun memiliki skor OHI-S tergolong baik $(25,6 \%)$; sedang $(30,24 \%)$; dan buruk $(2,4 \%)$, sedangkan yang memakai alat ortodontik cekat selama kurun waktu 1-2 tahun yaitu sebesar 4,6\% memiliki skor OHI-S tergolong baik; sedang (32,56\%); dan buruk (4,6\%). Berdasarkan hasil penelitian, tidak terdapat subyek yang memakai alat ortodontik lebih dari 2 tahun. Hasil uji Chi-Square memperoleh nilai $\mathrm{p}=0,060$ yang menunjukkan tidak terdapat hubungan bermakna antara pemakaian alat ortodontik cekat dengan status kebersihan gigi dan mulut siswa SMA Kristen 1 Tomohon.

Tabel 4. Hubungan pemakaian alat ortodontik cekat dengan status kebersihan gigi dan mulut siswa SMA Kristen 1 Tomohon

\begin{tabular}{|c|c|c|c|c|c|c|c|c|c|c|}
\hline \multirow{3}{*}{ Variabel } & \multicolumn{9}{|c|}{ Oral Hygiene Index Simplified } & \multirow{3}{*}{$\begin{array}{c}p \\
\text { value }\end{array}$} \\
\hline & & \multicolumn{2}{|c|}{ Baik } & \multicolumn{2}{|c|}{ Sedang } & \multicolumn{2}{|c|}{ Buruk } & \multirow[b]{2}{*}{$\mathrm{n}$} & \multirow[b]{2}{*}{$\%$} & \\
\hline & & $\mathrm{n}$ & $\%$ & $\mathrm{n}$ & $\%$ & $\mathrm{n}$ & $\%$ & & & \\
\hline \multirow{3}{*}{$\begin{array}{l}\text { Lama pemakaian } \\
\text { alat ortodontik } \\
\text { (tahun) }\end{array}$} & $<1$ & 11 & 25,6 & 13 & 30,24 & 1 & 2,4 & 25 & 58,24 & \multirow{4}{*}{0,060} \\
\hline & $1-2$ & 2 & 4,6 & 14 & 32,56 & 2 & 4,6 & 18 & 41,76 & \\
\hline & 2 & 0 & 0 & 0 & 0 & 0 & 0 & 0 & 0 & \\
\hline Total & & \multicolumn{2}{|c|}{30,2} & \multicolumn{2}{|c|}{62,8} & & 7,0 & 43 & 100 & \\
\hline
\end{tabular}

\section{BAHASAN}

Hasil penelitian menunjukkan bahwa subyek perempuan lebih dominan $(79,1 \%)$ daripada laki-laki (20,9\%). Hasil penelitian ini sejalan dengan penelitian yang dilaku- kan oleh Galaget al ${ }^{19}$ di Manado yang juga mendapatkan responden perempuan lebih dominan $(86,1 \%)$. Hasil penelitian lainnya yaitu oleh Anggraeni ${ }^{12}$ di Medan mendapatkan responden perempuan sebesar 
$53,33 \%$ sedangkan hasil penelitian Kudirkaite et $\mathrm{al}^{20}$ di Luthiania mendapatkan responden perempuan sebesar $64,48 \%$.

Berdasarkan hasil penelitian tersebut dapat diasumsikan bahwa subyek perempuan cenderung lebih memperhatikan estetik seperti keindahan, kebersihan dan penampilan diri sehingga mereka lebih memperhatikan kesehatan gigi dan mulutnya, sedangkan laki-laki kurang memperhatikan keindahan, kebersihan dan penampilan diri. ${ }^{21,22}$

Usia subyek dalam penelitian ini yaitu remaja dengan usia antara 15-17 tahun. Hasil penelitian menunjukkan bahwa usia 15 tahun mendominasi penggunaaan alat ortodontik cekat yaitu sebesar $53,5 \%$. Hasil penelitian ini sejalan dengan penelitian yang dilakukan oleh Farzanegan et $\mathrm{al}^{22}$ di Iran yang mendapatkan pemakaian alat ortodontik cekat paling banyak berada di usia 15-17 tahun. Demikian juga dengan penelitian Kavaliauskiene et $\mathrm{al}^{23}$ di Lithuana tahun 2018 menjelaskan bahwa pemakai alat ortodontik cekat terbesar $(45,9 \%)$ pada usia $14-15$ tahun. ${ }^{23}$

Remaja memiliki keinginan untuk merawat gigi melalui perawatan ortodontik agar mendapat kepuasan terhadap penampilan gigi. Pada remaja terjadi perubahan psikologis untuk tampil sempurna dan meningkatkan rasa percaya diri. ${ }^{24,25}$ Pada fase remaja ini terutama untuk remaja pertengahan yang berada dalam masa mencari jati diri yang mendorong timbulnya keinginan untuk mendapatkan yang terbaik khususnya gigi geligi yang sehat. ${ }^{26^{\circ}}$

Berdasarkan lama pemakaian alat ortodontik cekat untuk pemakaian kurang dari satu tahun didapatkan sebanyak 25 subyek $(58,1 \%)$ sedangkan pemakaian untuk 1-2 tahun sebanyak 18 subyek $(41,9 \%)$. Hasil penelitian ini selaras dengan penelitian Stefanni $^{27}$ di Medan yang menunjukkan bahwa lama pemakaian alat ortodontik cekat terbanyak pada pemakaian kurang dari satu tahun dengan jumlah responden 65 orang $(51,2 \%)$.

Lamanya pemakaian alat ortodontik cekat bervariasi sesuai tingkat kesulitannya. Perkiraan durasi rerata perawatan alat orto- dontik yaitu 2 tahun tetapi dalam kenyataan durasinya lebih lama dari waktu yang diperkirakan, khususya pada remaja. ${ }^{28}$ Subyek penelitian ini sementara menjalani perawatan ortodontik cekat dengan lama pemakaian yang berbeda tiap individu dan belum lama memakai alat ortodontik cekat. Hal ini terbukti dengan paling banyak subyek yang memakai alat ortodontik cekat dibawah 1 tahun.

Hasil pemeriksaan status kebersihan gigi dan mulut yang diukur dengan menggunakan OHI-S menunjukkan bahwa hampir seluruh subyek penelitian memiliki status kebersihan gigi dan mulut sedang $(62,8 \%)$. Hasil penelitian ini sejalan dengan penelitian Cantekin ${ }^{29}$ di Turki yang mendapatkan sebesar $76,47 \%$ subyek dengan status kebersihan gigi dan mulut kategori sedang. Demikian pula dengan penelitian Mararu $^{30}$ di Manado yang mendapatkan sebesar $53,49 \%$ subyek dengan status kebersihan gigi dan mulut kategori sedang.

Peneliti berasumsi bahwa kebersihan gigi dan mulut subyek yang berada dalam kategori sedang bisa dikatakan cukup meskipun kurang maksimal. Hal ini didukung oleh penelitian Basuni et $\mathrm{al}^{31}$ di Kabupaten Banjar yang menunjukkan bahwa tingkat pendidikan memiliki pengaruh terhadap kebersihan gigi dan mulut. Penelitian oleh Pintauli dan Hama$\mathrm{da}^{32}$ di Medan menyatakan kemungkinan besar seseorang dengan tingkat pendidikan yang rendah memiliki pengetahuan tentang kebersihan gigi dan mulut kurang.

Berdasarkan hasil uji Chi-Square diperoleh nilai $\mathrm{p}=0,060$ yang menunjukkan tidak terdapat hubungan bermakna antara pema-kaian alat ortodontik cekat dengan status kebersihan gigi dan mulut siswa SMA Kristen 1 Tomohon. Hasil penelitian ini sejalan dengan penelitian Dashari et al ${ }^{33}$ di Yogyakarta yang melaporkan bahwa tidak terdapat hubungan bermakna antara pem-kaian alat ortodontik cekat dengan status kebersihan gigi dan mulut $(\mathrm{p}=0,164)$.

Hasil penelitian ini menunjukkan tidak terdapat hubungan bermakna antara pemakaian alat ortodontik cekat dengan status kebersihan gigi dan mulut subyek pene- 
litian ini. Peneliti berasumsi hal ini disebabkan karena adanya perbedaan tingkat pendidikan subyek, karena semakin tinggi pendidikan seseorang maka semakin besar perhatian dirinya mengenai kesehatan. Sebaliknya, pendidikan yang rendah akan memengaruhi kemampuan seseorang dalam menerima informasi kesehatan dan pemahaman tentang kesehatan sehingga akan berpengaruh terhadap sikap seseorang dalam melakukan tindakan kesehatan. Notoatmodjo $^{34}$ berpendapat bahwa tingkat pengetahuan akan memengaruhi tingkat penguasaan responden terhadap derajat kesehatannya karena dalam pendidikan terjadi proses pembelajaran yang selanjutnya akan memengaruhi perilaku seseorang dalam melakukan tindakan pemeliharaan dan peningkatan kesehatan yang benar. $^{34,35}$

Subyek dalam penelitian ini sering mendapatkan informasi atau pengetahuan tentang pemeliharaan kebersihan gigi dan mulut, baik dari dokter yang merawat,orang tua, guru, masyarakat sekitar, maupun media sosial dan media elektronik. ${ }^{34}$ Hal tersebut didukung oleh penelitian Suci di Banda Aceh yang melaporkan bahwa tingkat pengetahuan mengenai kebersihan gigi dan mulut pada siswa Sekolah Menengah Atas menunjukkan tingkat per-sentase tertinggi pada tingkat pengetahuan cukup $(58,6 \%)^{35}$

Pemakaian alat ortodontik cekat memiliki desain yang membuat lebih sulit untuk menjaga kebersihan pada saat pemakaian yang mempermudah melekatnya plak lebih lama dan dapat meningkatkan risiko karies, gingivitis, dan kemungkinan terjadi penyakit periodontal yang membuat pemakai alat ortodontik cekat lebih susah untuk menjaga kebersihan gigi dan mulutnya karena kesulitan membersihkan gigi khususnya di sekitar bracket dan sepertiga makhota gigi pada tepi gingiva. ${ }^{13,36}$ Menurut Blais et al, ${ }^{37}$ pemakaian alat ortodontik cekat dapat menjadi faktor risiko terjadinya kebersihan gigi dan mulut yang buruk, yang dapat dihindari dengan perilaku kesehatan yang baik. Hal tersebut sejalan dengan hasil penelitian ini yang mendapatkan tidak adanya hubungan bermakna antara lama pemakaian alat ortodontik cekat dan kebersihan gigimulut. Subyek yang memakai alat ortodontik cekat dalam kurun waktu lama tapi dapat menjaga kebersihan gigi dan mulut dengan baik maka tidak akan berefek negatif terhadap kesehatan.

Pemakai alat ortodontik cekat khususnya remaja harus memahami dampak yang ditimbulkan alat ortodontik cekat terhadap kebersihan gigi dan mulut serta harus berkomitmen dan meningkatkan perhatian terhadap kesehatan dan kebersihan gigi dan mulut. Untuk itu diperlukan peran dari dokter gigi dalam memberikan motivasi dan instruksi yang benar dari awal hingga akhir perawatan alat ortodontik cekat. ${ }^{36,38}$ Pemakai alat ortodontik cekat harus diberikan arahan mengenai pencegahan seperti cara menyikat gigi, pemakaian dental floss, penggunaan pasta gigi berflourida dan penggunaan obat kumur, juga motivasi dalam rangka meningkatkan kebersihan gigi dan mulut. ${ }^{39}$

\section{SIMPULAN}

Berdasarkan hasil penelitian ini dapat disimpulkan bahwa tidak terdapat hubungan bermakna antara pemakaian alat ortodontik cekat dengan status kebersihan gigi dan mulut pada siswa dan siswi di SMA Kristen 1 Tomohon.

\section{SARAN}

Disarankan melakukan studi lanjut mengenai status kebersihan gigi dan mulut pada pemakai alat ortodontik cekat dengan melibatkan pendidikan, pengetahuan, dan perilaku subyek penelitian terhadap perawatan alat ortodontik cekat serta kebersihan gigi dan mulut. Juga disarankan melakukan sosialisasi tentang pentingnya kebersihan gigi dan mulut serta pemakaian alat ortodontik cekat dari perguruan tinggi khususnya dari kedokteran gigi atau dokter gigi spesialis ortodontik.

\section{DAFTAR PUSTAKA}

1. World Health Organization. Promoting oral health in Africa. Republic of Congo. 
WHO Regional Office for Africa, 2016; p. ix.

2. Ahuja V. Oral health related quality of life among Iowa adolescents [Thesis]. Iowa Research Online, 2013; p. 3.

3. Dewi O. Hubungan maloklusi dengan kualitas hidup pada remaja SMU Kota Medan tahun 2007 [Tesis]. Medan: Universitas Sumatra Utara; 2008; p. 1-4.

4. Rahardjo A, Maharani DA. A review of Indonesia's dental health-past,present and future. Int J Clin Prev Dent. 2014; 10(3):121-6.

5. Badan Penelitian dan Pengembangan Kesehatan. Riset Kesehatan Dasar. Jakarta: Departemen Kesehatan Republik Indonesia, 2007; p. 130.

6. Badan Penelitian dan Pengembangan Kesehatan. Riset Kesehatan Dasar. Jakarta: Departemen Kesehatan Republik Indonesia, 2013; p. 110.

7. Cobourne MT, DiBiase AT. Handbook of Orthodontics. British: Mosby Elsevier, 2010; p. 1.

8. Alawiyah T. Komplikasi dan resiko yang berhubungan dengan perawatan ortodonti. Jurnal Ilmiah WIDYA. 2017; 4:256.

9. Mantiri SC, Wowor VNS, Anindita PS. Status kebersihan mulut dan status karies gigi mahasiswa pengguna alat ortodontik cekat. eG. 2013;1:1.

10. Herwanda, Arifin R, Lindawati. Pengetahuan remaja usia 15-17 tahun di SMAN 4 Kota Banda Aceh terhadap efek samping pemakaian alat ortodontik cekat. Journal of Syiah Kuala Dentistry Society. 2016;1(1):79.

11. World Health Organization. Adolescent health. [cited 2018 feb 18]. Available from: http://www.who.int/topics/ adolescent_health/en/

12. Anggraeni UF. Perbandingan indeks plak pengguna pesawat ortodonti cekat pada murid SMA Swasta Harapan 1 dan SMA Negeri 1 Medan [Skripsi]. Medan: Fakultas Kedokteran Gigi Sumatera Utara; 2015.

13. Singh G. Fixed orthodontic appliances. In: Singh G, editor. Textbook of Orthodontics (2nd ed). New Delhi: Jaypee Publishers, 2007; p. 4, 240, 449-66.

14. Anuwongnukroh N, Dechkunakorn S, Kanpiputana R. Oral hygiene behavior during fixed orthodontic treatment.
OMICS International. 2017;7:3.

15. Al-Anezi SA, Harradine NWT. Quantifying plaque during orthodontic treatment. Angle Orthodontist. 2012;82(4):74853.

16. Atassi F, Awartani F. Oral hygiene status among orthodontics patients. Journal of Contemporary Dental Practice. 2010; 11(1): 1 .

17. Sariningsih E. Gigi Busuk dan Poket Periodontal sebagai Fokus Infeksi. Jakarta: Gramedia, 2014; p. 277.

18. Topaloglu A, Ertugrul F, Eden F, Ates M, Bulut H. Effect of orthodontics appliances on oral microbiota. J Clin Pediatr Den. 2011;35(4);433-6.

19. Galag CJR, Anindita PS, Waworuntu O. Status kebersihan mulut pada pengguna alat ortodonti cekat berdasarkan Oral Hygiene Index Simplified di Sekolah Menengah Atas Negeri 1 Manado. eG. 2015;3(2):299-300.

20. Kudirkaite I, Lopatiene $K$, Zubiene J, Saldunaite K. Age and gender influence on oral hygiene among adolescents with fixed orthodontic appliances. Stomatologija Baltic Dental and Maxillofacial Journal. 2016; 18(2): 63-4.

21. Memon AB, Jabbar A, Sheikh IA, Dahri WM, Malhi P, Rind SH. Plaque score during orthodontic treatment in relation to age and gender. Journal of the Pakistan Association. 2015;24(4):1003.

22. Farzanegan F, Heravi F, Tanbakouchi B, Noori E. Changes of oral health related quality of life and after fixed orthodontic treatment. Adv Dent \& Oral Health. 2016;2(4):1-4.

23. Kavaliauskiene A, Sidlauskas A, Zaborskis A. Relationship beetween orthodontic treatment need and oral health-related quality of life among 11-18-years-old adolescent In Lithuania. Int $\mathbf{J}$ Environ Res Public Health. 2018;15:1-17.

24. Fawzan AA. Reasons for seeking orthodontic treatment in Qassim Region: A pilot study. International Dental Journal of Student's Research. 2012;1:58-2.

25. Anderson LE, Arruda A, Inglehart MR. Adolescent patients treatment motivation and satisfaction with orthodontic treatment. Angle Orthodontics. 2009; 79(5):821-7. 
26. Deswita, Mayastaria T, Rahayuningsiha A. Hubungan kesehatan gigi dan mulut dengan konsep diri pada remaja di SMPN 7. Jurnal Garuda. 2013;9(2): $152-7$

27. Stefanni. Karakteristik dan motivasi pemakaian piranti ortodonti cekat pada siswa SMP dan SMA Bodhicitta dan Husni Thamrin Medan [Skripsi]. Medan: Universitas Sumatera Utara; 2013.

28. Lestari N, Puspitasari Y, Masdar TA. Hubungan lama penggunaan alat ortodontik cekat terhadap akumulasi plak dan $\mathrm{pH}$ saliva mahasiswa FKGUMI tahun 2017. As-Syifaa Jurnal Kedokteran Gigi Universitas Muslim Indonesia. 2018;10(1):126-33.

29. Mararu WP, Zuliari K, Mintjelungan $\mathrm{CN}$. Gambaran status kebersihan gigi dan mulut pada pengguna alat ortodontik cekat di SMA Negeri 7 Manado. eG. 2017;5(2):159-65

30. Cantekin K, Celikoglu M, Karadas M, Yildirim H, Erdem A. Effects of orthodontic treatment with fixed appliances on oral health status: A comprehensive study. Journal of Dental Sciences. 2011;6:235-8.

31. Basuni, Cholil, Putri DKT. Gambaran indeks kebersihan mulut berdasarkan tingkat pendidikan masyarakat di Desa Guntung Ujung Kabupaten Banjar. Dentino. 2014;2(1):18-23.

32. Pintauli S, Hamada T. Menuju gigi dan
Mulut Sehat Pencegahan dan Pemeliharaan (revisi). Medan: USU Press, 2012; p. 5-15.

33. Dashari Y, Ediati S, Ta'adi. Lama pemakaian alat orthodonti cekat dengan status kebersihan gigi dan mulut pada pasien yang berkunjung ke klinik gigi. Jurnal Gigi dan Mulut. 2014;(1)2:10610.

34. Notoatmodjo S. Promosi Kesehatan Teori dan Aplikasi. Indonesia: Rineka Cipta; 2005; p. 43,57.

35. Suci RA, Saputri D, Sungkar S. Gambaran tingkat pengetahuan mengenai kebersihan mulut pada siswa sekolah menengah atas yang menggunakan perangkat ortodonti (Survei di SMAN 3 Banda Aceh). Journal Caninus Dentistry. 2016;1(4):20-25.

36. Bhalajhi SI. Fixed appliances. In: Bhalajhi SI, editor. Orthodontics, the Art And Science (3rd ed). New Delhi: Arya (MEDI) Publishing House, 2004; p. 309-20.

37. Blais KK, Hayes JS, Kozier B, Erb G. Praktik Keperawatan Professional: Konsep dan Perspektif. Jakarta: EGC, 2006; p. 35.

38. Gill DJ. Orthodontics at Glance. England: Blackwell, 2008; p. 85, 88.

39. Derby ML, Wals MM. Dental Hygiene Theory and Practice. St Louis, Missourri: Saunders Elisevier, 2010; p. 267-77;401. 